University of Nebraska - Lincoln

DigitalCommons@University of Nebraska - Lincoln

Joshua Scottow Papers

Libraries at University of Nebraska-Lincoln

March 2007

\title{
Restoration Declensions, Divine Consolations: The Work of John Foxe in 1664 Massachusetts
}

Anne Myles

University of Northern lowa, anne.myles@uni.edu

Follow this and additional works at: https://digitalcommons.unl.edu/scottow

Part of the American Studies Commons

Myles, Anne, "Restoration Declensions, Divine Consolations: The Work of John Foxe in 1664 Massachusetts" (2007). Joshua Scottow Papers. 8.

https://digitalcommons.unl.edu/scottow/8

This Article is brought to you for free and open access by the Libraries at University of Nebraska-Lincoln at DigitalCommons@University of Nebraska - Lincoln. It has been accepted for inclusion in Joshua Scottow Papers by an authorized administrator of DigitalCommons@University of Nebraska - Lincoln. 
Dr. Anne Myles, of the University of Northern Iowa, has recently published an article describing her discovery of a previously unattributed work of Joshua Scottow: Divine Consolations for Mourners in Sion (1664). Her excellent article is titled "Restoration Declensions, Divine Consolations: The Work of John Foxe in 1664 Massachusetts," and can be found in The New England Quarterly, March 2007, Vol. 80, No. 1, Pages 3568. It is available online at:

\section{http://www.mitpressjournals.org/doi/abs/10.1162/tneq.2007.80.1.35}

She writes: "In 1664, a text appeared in New England that addressed itself to the uncertainty of the present by once again reaching back into the past - in this case, the past of over a century earlier - to let the dead speak. The anonymous tract, titled Divine Consolations for Mourners in Sion, published without an imprint, has survived in only two copies, one in the collections of the American Antiquarian Society and one at Trinity College in Dublin. Listed in the English Short-Title Catalog but never included in Evans's Early American Imprints, Divine Consolations has apparently gone entirely unnoticed in the history of Puritan scholarship. While the tract is clearly problematic in matters of attribution and publication, it also has much to offer us as we seek to understand the mentality of 1660s Massachusetts and the history of the book in early America. Comprised of a preface directed toward the people of Boston and New England, followed by an extract that reprints the section of John Foxe's Acts and Monuments related to the examination and letters of Marian martyr John Careless, combined with several letters from other Protestant martyrs, Divine Consolations is by far the first publication in America of any portion of the work best known as the Book of Martyrs; more than that, it seems to represent the first occasion on which material previously published in England - albeit an extract rather than a book proper-was printed in New England."

In addition to building a convincing case for Scottow as "compiler" of the work, she also discusses his translations of Guy de Brès, the checkered career of Marmaduke Johnson, the micro-politics of 1660s Massachusetts, martyrology, and Quakerism.

\section{Highly recommended.}

